\title{
Peat forest Rehabilitation in Central Kalimantan and REDD+: Conflicting Roles of Government Agencies
}

\author{
Farwiza Farhan ${ }^{1}$, Medrilzam $^{2}$ and Sebastian Thomas ${ }^{3}$ \\ ${ }^{1}$ Leuser Ecosystem Management Authority (BPKEL), Aceh Provincial \\ Government, Aceh, Indonesia \\ ${ }^{2}$ School of Agriculture and Food Sciences, The University of Queensland, \\ Brisbane, 4072 QLD, Australia \\ ${ }^{3}$ School of Business, The University of Queensland, \\ Brisbane 4072 QLD, Australia
}

\begin{abstract}
Peat forests are considered to be one of the largest reserves of terrestrial carbon in the world, and play an important role in storing atmospheric carbon. Indonesia is home to nearly half of the world's tropical peatlands, and as the country with the world's second-highest deforestation rate (after Brazil), these peatlands are being severely degraded. This paper uses the former Mega Rice Project area of Central Kalimantan to explore the role of government agencies in the development and implementation of Reduced Emissions from Deforestation and forest Degradation (REDD) schemes in Indonesia. The Indonesian Government is committed to reducing emissions from deforestation, as well as rehabilitating degraded forest areas. As Indonesia's legislative system is still maturing, policy and regulatory decisions are often made without thorough planning, and frequently conflict with one another. The research presented here identifies contradictory regulations and overlaps in the responsibilities of government agencies directly involved in elements of REDD+ policy, principally in regard to forest governance and land tenure in project areas.
\end{abstract}

Keywords: deforestation, Indonesia, carbon offsets, sustainable development, climate policy.

\section{INTRODUCTION}

The Government of Indonesia has established a suite of strategic policy imperatives and targets for its environmental regulatory framework and natural resource management. Indonesia has committed to reducing emissions from deforestation and rehabilitating degraded forest areas and is engaging with the international community to achieve these ends. Indonesia's legislative system is still maturing, however, and policy and regulatory decisions are often made without adequate consultation, and often result in duplication of responsibilities or administrative conflicts. Omissions and loopholes in regulations have created 
complications in the implementation of these policies. The process is further complicated by the division of authority and responsibility between three levels of government - national, provincial and district - each with its own agenda. This paper examines the role of various government departments in supporting the development of policy and implementation of Reduced Emissions from Deforestation and forest Degradation Plus (REDD+) schemes, using the rehabilitation efforts in the former Mega Rice Project area of Central Kalimantan as a case study. Policy choices in regard to Indonesia's peatlands are of crucial importance, because these areas play an important role in terms of carbon storage and emissions, spatial dimensions, human communities, biodiversity and environmental services.

Peat is formed through the incomplete decomposition of plant material that accumulates in wet environments over thousands of years (Jaenicke et al., 2008). Inevitably, through this accumulation, peatlands store large amounts of organic carbon (Byron and Shepherd, 1998; Hirano et al., 2006) and are considered to be one of the largest terrestrial carbon sinks (Page et al., 2002; Jauhianen et al., 2005). It is estimated that $27.1 \mathrm{M}$ ha of tropical peat forest in South East Asia contain at least $42,000 \mathrm{M}$ tonnes $(\mathrm{Mt})$ of carbon (Silvius and Diemont, 2007) with peat thickness reaching $20 \mathrm{~m}$ in some areas (Page et al., 2000; Jaenicke et al., 2008). Due to their fragility, the levels of disturbance they are currently experiencing, and their high carbon content, the stability of peatlands has important implications for climate change (Boehm and Siegert, 2001, Page et al., 2002), and compared to other endeavours, the effort to protect peatlands as a carbon sink could make a major and relatively low-cost contribution to climate change mitigation (Diemont et al., 2002).

Peatlands are unique ecosystems. They are nutrient-poor and have acidic soil, which render them unsuitable locations for agriculture, yet they have rich biodiversity and are home to some of the world's most endangered species, making them doubly valuable as areas for protection (Rieley and Page, 1996). A characteristic that differentiates tropical peat forests from other tropical forests is their waterlogged nature, making them difficult to access (Phillips, 1998). Unfortunately, , the singular accumulation of ecological wealth present in tropical peatlands does not discourage economic exploitation that leads to their degradation (Phillips, 1998). Like other forest types in most developing countries, tropical peatlands in Indonesia suffer from largescale degradation due to timber production (Sorensen, 1993; Curran et al., 2004), land conversion (Curran et al., 2004), drainage construction, and agriculture (Hirano et al., 2006). Indonesia contains nearly half of the world's tropical peatlands (van Beukering et al., 2008). It is also considered the world's third largest carbon emitter, mainly due to peat degradation, deforestation and anthropogenic fires (Silvius and Diemont, 2007). Indonesia's Kalimantan peatlands have suffered unprecedented degradation in the last two decades, most notably as a result of the initiation of the Central Kalimantan Mega Rice Project (MRP) in 1996 (Boehm and Siegert, 2001; Page et al., 2002), and the subsequent large-scale forest fires in 1997.

The fire was initially intended as a cost-effective land-clearing measure (Page et al., 2002; Peluso, 2006), but a drainage canal that had been constructed the previous year had lowered the local water table, draining Central Kalimantan's peat bogs, and making them susceptible to fire. Exacerbated by a drought year and the effects of El Niño, the fire quickly spread and become catastrophic (Aldhous, 2004). The peat 
forest fire event in 1998 is estimated to have released $13-40 \%$ as much carbon dioxide as a typical year's global emissions from the burning of fossil fuels (Aldhous, 2004).

Deforestation and forest degradation issues in Indonesia are symptoms of the broader issues of social, economic and political instability. Resource-rich nations, including Indonesia, often turn to their natural resources to fuel economic development. Such utilization is generally conducted in an ecologically unsustainable manner, while simultaneously emitting large volumes of carbon dioxide through inefficient industrial practices, both of which have grave implications for the environment. In 2005, a group of scientists introduced the concept of offering financial compensation to reduce deforestation with the aim of reducing the allure of large-scale deforestation in developing countries as well as encouraging developing nations to participate in the Kyoto Protocol (Santilli et al., 2005). This concept later came to be known as reducing emissions from deforestation (RED). As the negotiation process continued, the focus of RED shifted from solely reducing emission from deforestation to include a broader carbon management strategy, involving forest rehabilitation and carbon stock enhancement, known as REDD+ (Campbell, 2009).

The idea of using financial compensation to reduce deforestation in developing countries was first submitted by Papua New Guinea and Costa Rica in 2005 (Alvarado and Wertz-Kanounnikoff, 2007), acknowledging the economic rationale that is typically used to justify large-scale deforestation. The economic rationale for deforestation often involves the high financial return of both timber extraction and the conversion of forest to agricultural land (Strassburg et al., 2009). Also, the cost of forest conservation is generally considered to be too high for these resource-rich nations (Chatterjee, 2009). Therefore, when the concept of compensated forest preservation was proposed in 2005, it was seen as a panacea that would address the economic motives of deforestation (Santilli et al., 2005), both reducing emissions from forestry operations and generating a vested interest in forest and biodiversity conservation (Gaveau et al., 2009, Venter et al., 2009a, Venter et al., 2009b). However, in the five years since the concept was introduced, the implementation of good forest governance through RED-type schemes has been shown to be problematic: Unclear land tenure creates conflicts over landownership and benefit sharing between the government, indigenous communities and large companies that operate in forest concessions and plantations.

The development of REDD+ policy embraces many factors, including land tenure, the permanence of carbon stored, indigenous rights, community empowerment, good forest governance and international funding. This paper examines the regulatory aspects of peatland rehabilitation efforts and the potential for development of effective REDD+ policy for peatlands in Indonesia. Specifically, this discussion refers to the peatland rehabilitation efforts that take place in the previously Mega Rice Project area in Central Kalimantan.

\section{THE CENTRAL KALIMANTAN PEAT FOREST AND THE MEGA RICE PROJECT}

Central Kalimantan contains about $3 \mathrm{M}$ ha of peatland, making it one of the most important peatland areas in South East Asia (Parish, 2002). The peat forest in Central 
Kalimantan is an important source of livelihoods for the indigenous community living in the area providing land for farming and non-timber forest products (Boehm and Siegert, 2001).

The Mega Rice Project (MRP) was initiated by former Indonesian President Soeharto in 1995. The plan to turn Borneo into the rice bowl of Indonesia came about because the fertile agricultural land of Java was in demand for housing and industrial development (Aldhous, 2004). Indigenous peoples and local communities (of more recent immigrants) in Central Kalimantan have cultivated rice in the area for many generations without serious environmental degradation. Notably, subsistence rice cultivation took place on a very small scale, without major landscape modifications (Boehm and Siegert, 2001). In contrast to traditional agriculture, the MRP was conducted on a massive scale (Figure 1). For example, one of the first steps of the MRP was the construction of a macro-network of canals, which in Java served to facilitate effective soil drainage and crop irrigation (Aldhous, 2004). Unfortunately, Borneo's peatlands have a different topography than the land in Java, and drainage exposed soils that were too acidic to grow rice (Aldhous, 2004).

From its inception the MRP has been surrounded by controversy. In September 1995, peatland experts from around the world gathered at an international symposium in Palangkaraya to discuss the Indonesian Government's plan to convert $1 \mathrm{M}$ ha of peat forest into rice fields. The assembled experts warned the government about the unsuitability of peatlands for large-scale agriculture, and their consensus was that Indonesian peatlands should be preserved in their natural condition (Rieley and Page, 1996). Prior to receiving this advice, however, governments in South East Asia had solicited the advice of development agencies regarding peatland development. These agencies, not having the benefit of a comprehensive understanding of peatland ecology, were unaware of the enormous environmental value of peat forests, and had consistently advised the government to sacrifice peatlands in favour of economic development (Sorensen, 1993). In addition, lack of appropriate planning and effective cooperation between project participants were among the main reasons for the failure of the project:

The technical teams involved in the design of the MRP planned for a cautious and phased development, starting in the Blok A area earlier identified as being suitable. A macro-network of drainage and supply canals was designed to improve water management conditions. Unfortunately, works on the macro-infrastructure did not follow the same phasing, and started in the whole area on the basis of pre-designs, and ahead of the hydrological and topographical surveys and the environmental impact assessment (Giesen et al., 2009, p. 7). 


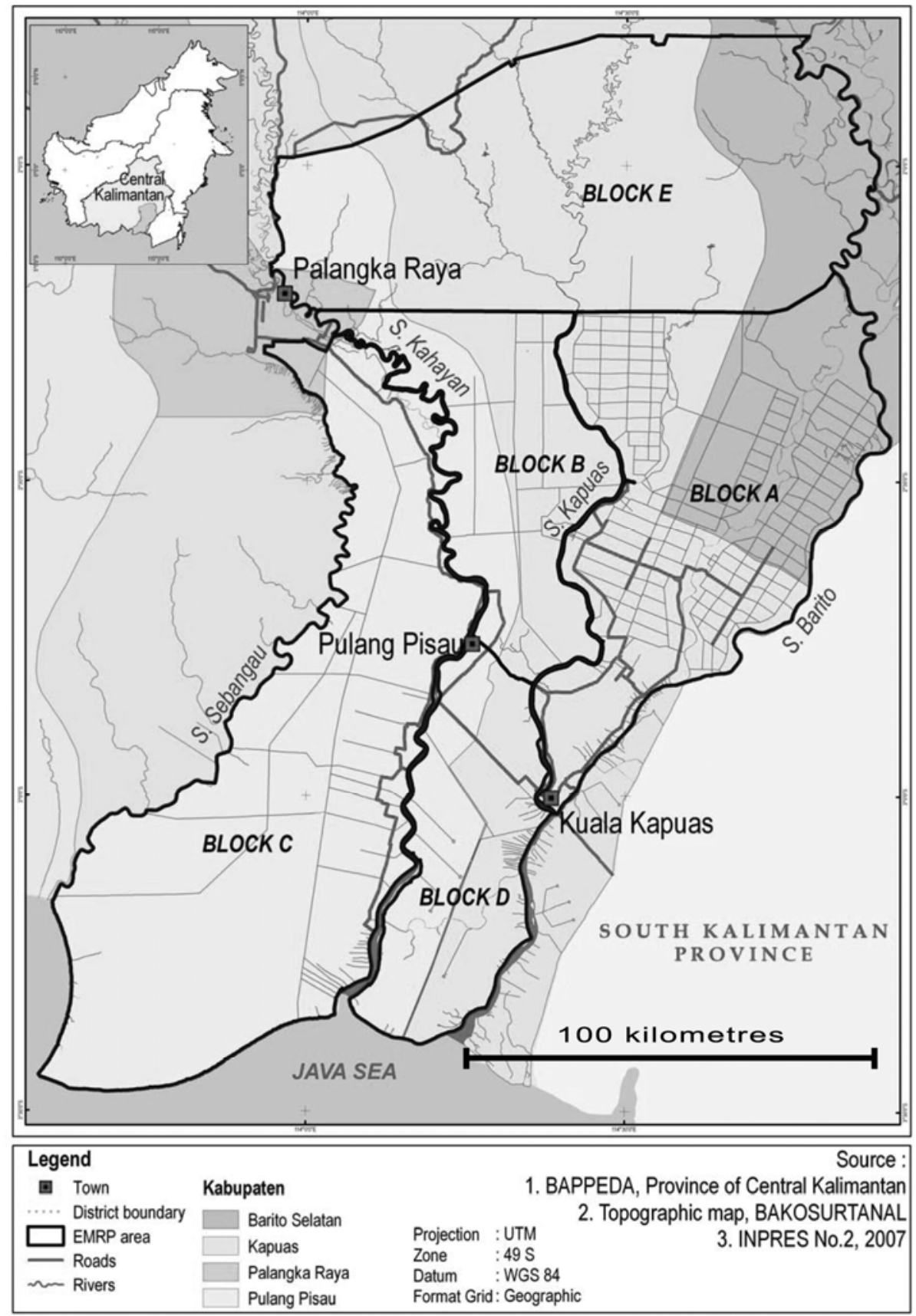

Figure 1. The former Mega Rice Project area in Central Kalimantan Province, Indonesia, on the island of Borneo

Source: Euroconsult-Mott Macdonald and Deltares (2008) 
The drainage canal system caused severe damage to peat hydrology, resulting in excessive water discharge, followed immediately by the large-scale drying of peat, making the peatlands susceptible to fire (Page et al., 2002). Historically, Borneo's indigenous Dayak people have exercised slash-and-burn land-clearing techniques to make way for agriculture (Boehm and Siegert, 2001), often in the form of rotational or shifting cultivation (Peluso, 2006). This practice was used because it was considered the most cost-effective means to prepare new agricultural land (Dauvergne, 1998, Boehm and Siegert, 2001; Peluso, 2006). Unfortunately, this slash-and-burn method was also adopted for the project and implemented on a vast scale (Boehm and Siegert, 2001). The land-clearing fires quickly began to burn out of control, which created massive forest fires that lasted for months. The fires quickly produced a haze that blanketed much of Borneo and South East Asia (Aldhous, 2004). The fires burned $0.73 \mathrm{M}$ ha of peat forest in Central Kalimantan and released between 0.81 to $2.57 \mathrm{Gt}$ of carbon dioxide (Page et al., 2002). Soon after the devastating 1997 forest fire and the 1998 political turbulence that overturned the Soeharto dictatorship, the project was abandoned (Aldhous, 2004). Even given the early termination of the MRP, the project caused severe degradation to the Kalimantan peat forest, and the land cleared in preparation for the MRP as also provided access to previously remote and inaccessible forest, making it vulnerable to illegal loggers and forest squatters (Parish, 2002, Vayda, 2010). During the 1997-98 El Niño event, peat forest fires in the ex-MRP area were exceptional in extent and volume of carbon emissions released, and fires have become repeated occurrences in the degraded peatlands of Central Kalimantan in drier years. In 2006, the province of Central Kalimantan was judged to have the highest number of fire hotspots in Borneo during the drought period, numbering about 40,000 hotspots (Siswanto, 2010). The concentration of peat fire hotspots in the ex-MRP area is illustrated in Figure 2.

In the past, it was common practice for government officials in Indonesia to blame traditional farmers for out-of-control forest fires. During the 1997 fires, however, reporting by the international and independent media made it clear that the fires were caused by deliberate land-clearing activities, often with explicit government endorsement (Byron and Shepherd, 1998). Peat fires are exceptionally difficult to extinguish and can burn for years, releasing lhugeamounts of carbon dioxide into the atmosphere (Dauvergne, 1998). The forest fires did not only affect the MRP area of Central Kalimantan; they spread quickly, and within a few month of the first blaze, thousands of fires were reported burning on the island of Borneo (Dauvergne, 1998). Inevitably, these fires spread to other provinces in Borneo including East Kalimantan, which was also experiencing severe burns (Hoffmann et al., 1999). While research indicates that there is a direct correlation between El Niňo events, drought conditions in Borneo and the extent of fire hotspots in Central Kalimantan, anthropogenic land use and agricultural activities, including the slash-and-burn clearing of forests, have resulted in increasing frequency, extent and severity of fires in the ex-MRP area (Putra et al. 2008; Field et al. 2009) Figure 3 shows burned forest areas from 1984 to 2007, and the increase in fire hotspots which occurred as a result of the forest fires in that period. 


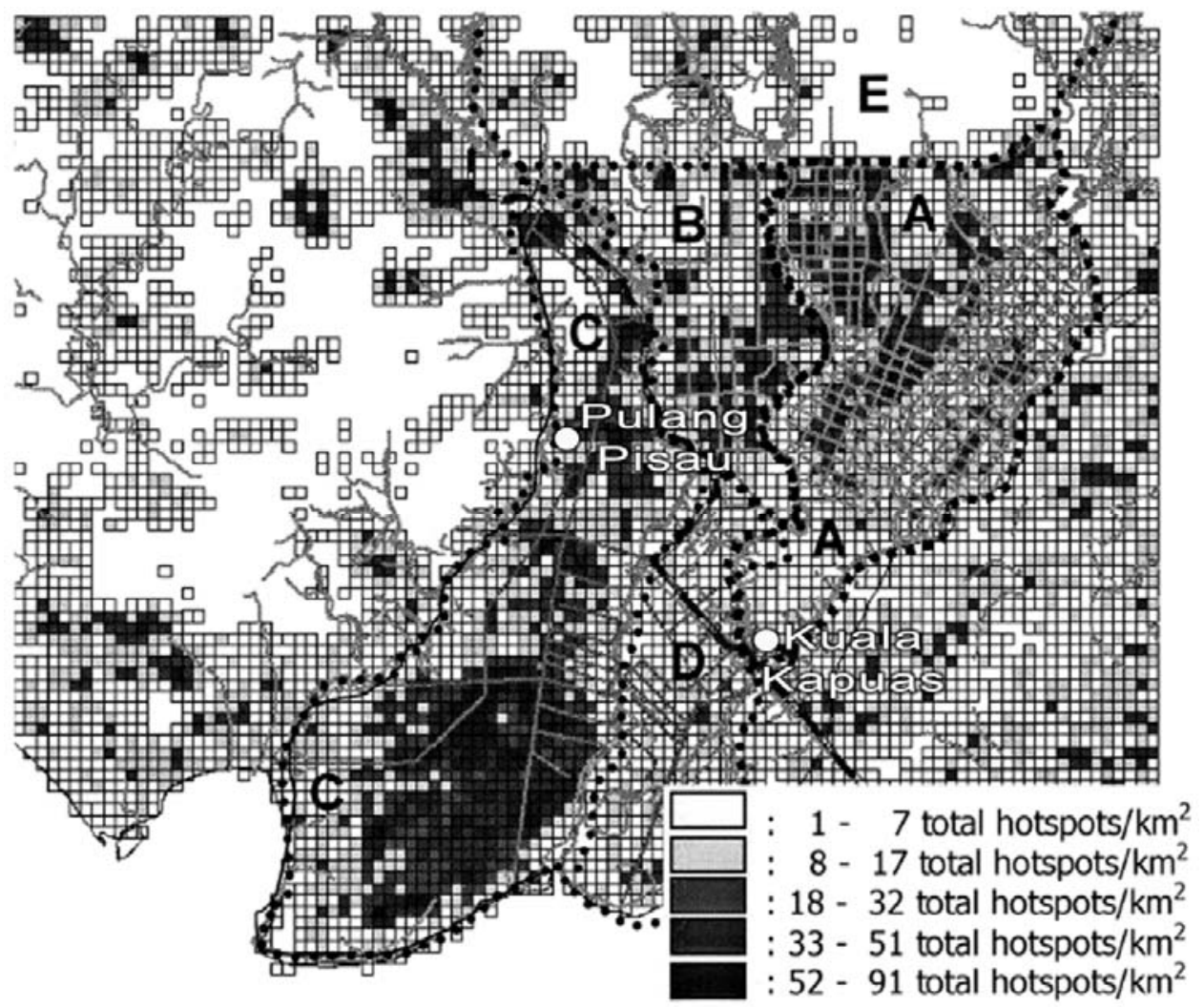

Figure 2. Peak fire incidence in Central Kalimantan from 1997 to 2007

Source: Putra et al. (2008)

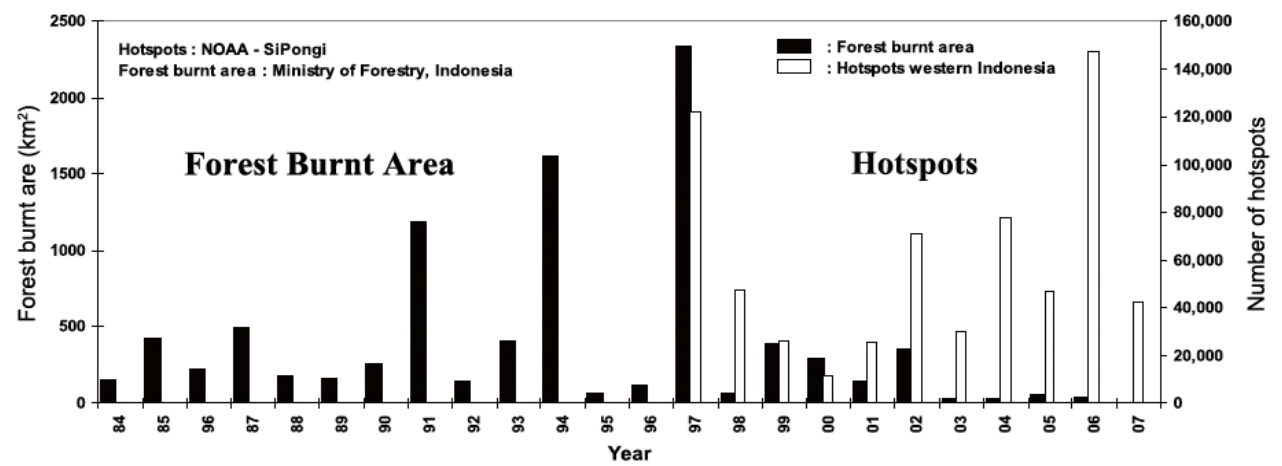

Figure 3. Burned area and number of hotspots in western Indonesia from 1984 to 2007 Source: Putra et al. (2008) 
In 1999, soon after the MRP was abandoned, there were several attempts to rehabilitate the peat forest. However, it was only in 2007 that President Susilo Bambang Yudhono released official instructions to restore the area. Presidential Instruction No. 2 of 2007 (referred to as Inpres 2/2007) provided guidance to the relevant government departments to assist in peat forest rehabilitation and conservation, while at the same time increasing agricultural development and community empowerment.

The Department of Forestry was to develop a 'master plan' for peatland rehabilitation and conservation. At the same time, the Department of Agriculture was to develop its own 'master plan', with the aim of expanding palm oil and rubber plantations in 'degraded peatland less than $3 \mathrm{~m}$ deep' (Euroconsult-Mott Macdonald and Deltares, 2008). The rehabilitation process was meant to be coordinated and supervised by BAPPENAS (Badan Perencanaan Nasional, the National Planning Agency), using an adaptive methodology for improvements based on new knowledge gained throughout the implementation of the rehabilitation project. These steps were taken specifically to 'avoid the mistakes of the past,' made due to carelessness and a lack of integrated planning.

\section{CHALLENGES TO EFFECTIVE IMPLEMENTATION OF REDD MECHANISMS IN INDONESIA}

The financial compensation programs known as REDD and REDD+ have become a priority for many tropical developing countries, including Indonesia (UN-REDD, 2010). The initial commitment to curb deforestation was expressed at COP13 in Bali in 2007, and by the end of 2008 Indonesia had become the only developing country that had passed national legislation intended to provide a comprehensive model for REDD activities ${ }^{1}$ (Terrestrial Carbon Group, 2009).

When it was initiated, the focus of REDD was reducing carbon emissions from deforestation. However, as the agenda moved towards landscape-scale carbon management, activities to rehabilitate, restore and reforest areas have been included in the scheme, with the purpose of enhancing carbon storage (Campbell, 2009). Central Kalimantan peat rehabilitation is an urgent matter and will be funded through existing department budgets; as the possibility for carbon financing emerges. However, it is likely that projects will also be financed through REDD+ mechanisms (EuroconsultMott Macdonald and Deltares, 2008).

Provincial governments are pursuing REDD schemes as an alternative to forest development. Unfortunately these efforts are hampered by misunderstandings and insufficient alignment with national level processes. While these initiatives deserve support, better communication between provincial governments and the Ministry of Forestry is essential to make REDD mechanisms successful in the long term (UNREDD, 2010).

\footnotetext{
${ }^{1}$ The national arrangements for REDD activities are set out in Forestry Ministry Regulation No. P.68/Menhut II/ 2008 on REDD Demonstration Activities.
} 
There are parties that express scepticism over Indonesia's commitment to reducing its emissions from deforestation and forest degradation, speculating that the primary motive for adopting REDD mechanisms is financial gain (Verchot et al., 2009), because nearly half of Indonesia's greenhouse gas emissions come from land-use change and the forestry sectors (Siswanto, 2010). This argument could be dismissed on the grounds of the legal effort the Indonesian Government has made to show its level of seriousness; however, Indonesian REDD regulation is notably immature and does not consider many key aspects of credible REDD implementation.

Challenges to the implementation of REDD schemes in the Indonesian context include constraints with regard to forest governance policy, land tenure, licensing and permit allocation, domestic transmigration, fire management and macro-infrastructure, sustainable peatland management and conservation, and the allocation of responsibilities and authority related to decentralization in Indonesia.

\section{Poor Quality of Forest Governance}

The forestry sector is perhaps one of the most complicated areas of governance in Indonesia, with great potential for negative consequences if forests are mismanaged. Valuable forest resources are at the root of conflicts over power and authority between political and business interests (Djogo and Syaf, 2003). Although governments do not have unlimited or exclusive powers of forest management, they do have a singular capacity to dictate acceptable courses of action to both individuals and businesses. The likelihood of success in combating illegal activities in the forestry sector will largely depend on the national government. When the government is affected by systemic corruption, its capacity to fight illegal activities is constrained (Contreras-Hermosilla, 2001). In Indonesia, forestry law is generally framed to accommodate the needs of commercial and political entities, often overriding the rights of local communities to utilize forest resources, which in some cases they have been managing for generations (Pye-Smith, 2010). Misguided ideas of 'good forest governance' were translated as isolating the forest from its people; this was particularly true when the first forestry law was passed in 1967. Millions of forest dwellers were alienated from their traditional forestland and the subsistence livelihoods it provided. Small-scale harvesting of wild fruit, collecting firewood, and clearing small plots to grow rice became illegal over much of Indonesia (Pye-Smith, 2010). Moreover, Colchester et al. (2003, p. 28) described the history of forest management in Indonesia as follows:

Indonesia exemplified to an unusual degree the intrinsic political, social, and institutional weaknesses of 'scientific forestry'. A centralized approach to forest management has denied community rights, favoured the emergence of corrupt elite, established a technocratic forestry bureaucracy, and overseen a sustained overharvesting of timber and misallocation of forestland for over 50 years. The resulting political economy of logging has created huge barriers to those promoting community forestry. Additional obstacles are erected by the government's ethnocentric and assimilationist social policies towards forest dwellers. The land tenure system provides very weak recognition of forest customary rights, and ...denies collective rights to forestlands. 
Indonesian government officials are infamous for their level of corruption; it has become a public secret that elections are often controlled by the politics of money (Djogo and Syaf, 2003), because the 'price' for a Bupati (head of district government) seat is often set by the parliament. Therefore, once a person is elected and inaugurated as a Bupati, the money spent during the election period will be recovered through granting authorization of logging permits to the private companies that funded this person's campaign (Djogo and Syaf, 2003).

Peatland rehabilitation in Central Kalimantan is a complex issue in itself; it requires integrated management involving various stakeholders with disparate objectives. The inclusion of REDD + in the proposed rehabilitation funding mechanism has substantially increased the level of policy complexity by expanding the array of stakeholders and regulations. Past policies in forestry and agricultural development have had direct impacts on the rate of deforestation in Indonesia. Resettlement and fiscal policies, in particular, have major implications for Indonesian forests.

\section{Domestic Transmigration as a Challenge to Effective Governance}

Indonesia is a country with population of more than 200 million people spread over five main islands and hundreds of smaller islands. Due to disparities in development, the majority of the population is concentrated in Java, Madura, and Bali, the most developed islands in Indonesia. Domestic transmigration dates back to the colonial period; in 1905 the Dutch colonialists sought to expand agriculture beyond Java (Levang, 2003), but major population movement from Java, Madura and Bali to other islands in Indonesia was encouraged by President Soeharto as part of the strategy to reduce political unrest and rebel movement in less-developed areas of Indonesia (Levang, 2003).

Since the Soeharto period, directing transmigration has been a major part of governance in Indonesia, and Presidential Instruction 2/2007 proposed that the Department of Employment and Transmigration move about 46,500 families to the Central Kalimantan area, based on the target of 93,000 ha of new irrigated rice fields (Euroconsult-Mott Macdonald and Deltares, 2008). However, peatland areas allocated for these transmigrants, have proven to be unsuitable for settlement and agricultural development. At the same time, the Central Kalimantan Provincial Government proposed the development of a road and rail network across the former MRP area to increase connectivity and facilitate the transport of people and commodities between Central Kalimantan and provincial cities and ports. Such development would undermine the objectives of Inpres 2/2007 to rehabilitate the degraded area of ex-MRP in Central Kalimantan (Euroconsult-Mott Macdonald and Deltares, 2008).

Historically, transmigration has created conflict, especially over land tenure and forest ownership (Levang, 2003). Land allowances for immigrants are often insufficient or infertile, encouraging these immigrants to imitate indigenous practices in obtaining land for agriculture through slash-and-burn and shifting cultivation techniques, which become common means of acquiring agricultural land from forested areas. 


\section{Land tenure and Forest Ownership Issues}

In the development of effective REDD+ policy, resource tenure is one of the key factors in shaping the distribution of risk, costs and benefits (Cotula and Mayers, 2009). In Indonesia, navigating the regulations of land tenure and landownership in forest areas (or areas classified as forest) to gain a clear legal determination of land rights can be a difficult exercise. Under the Constitution Law 1945, the government acknowledges and honours the customary rights of regional authorities and traditional communities over their land. Land rights are further regulated by Forestry Law 41/1999, which describes a customary forest as 'state forest that is located within the boundary of traditional communities' areas'. The law does not, however, provide explicit definition of the term 'traditional communities', and this lack of clarity has created complications in law enforcement. Furthermore, the law does not recognize absolute ownership by the indigenous community of their territories, but rather grants rights to manage and utilize the area given the condition that 'the indigenous communities are evidently in place and their presence is acknowledged' (Forestry Law 41/1999). This lack of unequivocal rights has the potential to greatly complicate policy implementation. For instance, in a land tenure case in Sumatra, the local people claimed ownership of a block of land within a nature reserve, backed by a legal certificate from the National Land Agency (Djogo and Syaf, 2003). The nature reserve was classified as a conservation forest area, and could not be owned by individuals, or even become a communal property. This case provides a clear example of contradictory regulations between forestry and the authority of the National Land Agency.

Under customary systems of landownership in forested areas in Indonesia, rights to fallow land and secondary forest were retained by whoever had first cleared the land (Otsuka et al., 2008). This customary principle was adopted by locals and immigrants living in and around the forest area to secure their rights to a block of land. There is a degree of fear among local people that, if they do not secure rights to their traditional land, they will lose out to migrants and large companies in the race for land at the forest frontier. The government (or government-sponsored project developers) acquires land for large-scale agricultural projects and forestry development programs by using clear-cutting and fire, followed by planting, which sets examples for local people. Clearing forest and planting cash crops becomes a mechanism for confirming land-use rights in a way that is recognised nationally (Byron and Shepherd, 1998).

Conflicts over a particular block of land often arise when the allocation of permits and land certificates is not integrated with appropriate planning that involves on-theground mapping and environmental impact assessment. In accordance with its agricultural development plan, Inpres 2/2007 on peatland degradation in the ex-MRP in Kalimantan allocated 17,500 ha of land for palm oil and rubber plantations (Euroconsult-Mott Macdonald and Deltares, 2008); however, at the same time the district government of Central Kalimantan issued 28 plantation permits, covering a total area of nearly 400,000 ha. Half of this area is located within protected forests, and includes about 120,000 ha of peatland of more than $3 \mathrm{~m}$ in depth (EuroconsultMott Macdonald and Deltares, 2008). Experts strongly advised the central government to revoke the excess permits, but this has not happened, and given the circumstances and the history of relationships between the government and palm oil plantation 
companies, there is little reason to expect that this revocation will occur. While plantation companies made modest reductions to their clearance costs per hectare through the use of fire, they caused billions of dollars of damage to the citizens of both Indonesia and neighbouring countries in form of smoke and haze that blanketed the region (Byron and Shepherd, 1998).

In May 2010, the Indonesian Government agreed to place a two-year moratorium on deforestation, banning both legal and illegal logging (Reklev, 2010). Paradoxically, however, the President assured investors that the government would still honour the contract to expand further palm oil and rubber plantations although such expansion might require forest and land clearing (Suharmoko, 2010). As part of the agreement, the Indonesian Government formed the 'Indonesia REDD+ task force' - a body which will engage in REDD+ policy research and implementation and which will directly report to the President, in addition to the National Agency on Climate Change and the Department of Forestry (which currently oversees REDD+-related activities in Indonesia).

\section{Plantation Permits as a Challenge to Conservation}

There are three levels of government directly involved in the issuance of plantation permits. Due to decentralization policies, district and provincial governments have the authority to issue permits for companies to develop plantation areas, a situation fostered by the central government's incentives to expand palm oil and rubber plantations. The effects of these incentives are apparent in the vast disparity between the area of land originally allocated for new plantations (17,500 ha) and the amount of land that has been allocated under provincial new plantation permits (almost 400,000 ha within ex-MRP areas). This includes the 120,000 ha of these new plantations located within areas of deep peat $(>3 \mathrm{~m})$ which were allocated by federal policy for conservation. The Department of Forestry is responsible for managing conservation forests, and regards issuance of these permits as unlawful. Also, these permits have been issued without environmental impact assessments (called Analisis Dampak Lingkungan or AMDAL), which need to be approved by the Department of Environment through the Environmental Control Agency (Badan Pengendalian Dampak Lingkungan or Bapedal). Therefore, the Department of Forestry has been encouraged to revoke these permits and terminate operations of these companies.

\section{Fire Prevention and Management, Spatial Management and Macro- Infrastructure}

Despite disagreements between several parties, it is generally accepted that forest fires in Kalimantan peat forests are anthropogenic; fires have been deliberately set as a means to claim ownership of an area due to competing land claims between government, private companies and local people (Byron and Shepherd, 1998). Fire also functions as a way to reassert landownership in the struggle between the indigenous people of Kalimantan and immigrants from Java. These factions often use fire carelessly to clear land when their allocated land proves too small or too infertile to support their households (Byron and Shepherd, 1998).

Forest fires are a critical problem in peat forest deterioration, and the responsibility to prevent fires is shared between all stakeholder groups: governments, corporations, 
NGOs and communities. The national agency for disaster management (Badan Nasional Penanggulangan Bencana or BNPB) has the responsibility to coordinate prevention of and response to fires (BAKORNASPB, 2010), while the Department of Public Works has been constructing dams to re-establish the water table in the exMRP area (Euroconsult-Mott Macdonald and Deltares, 2008). The Departments of Forestry and Environment share the responsibility of preventing the use of fires in agricultural development and land clearing (Giesen et al., 2009).

\section{Decentralization of Policy Development and Implementation in Indonesia}

The larger issue of Indonesia's political circumstances and reform agenda also affects forest governance. During the political turmoil of 1997 and 1998, many of the regions in Indonesia demanded independence and soon after the fall of President Soeharto in 1998, a decentralization agenda emerged as a platform of the reformed government (Djogo and Syaf, 2003). This decentralization was one of the central strategies to improve a political and economic situation that was in deep turmoil (Djogo and Syaf, 2003).

The powerful voices of the people that brought down Soeharto's 'New Order' dictatorship demanded a complete rearrangement of governance structures and mechanisms, mainly by restructuring the division of power and authority between central and regional governments (Djogo and Syaf, 2003). At that time, many perceived decentralization as a broad-spectrum solution that would improve the regional social, political and economic situation as well as strengthen the unity of the nation (Djogo and Syaf, 2003).

The terms decentralization and autonomy are often used interchangeably; however their meanings can be interpreted differently. Decentralization refers to the distribution of administrative management from the central government to provincial governments. Autonomy results from the devolution of power from the central government to regional and district governments. Yuwono (2001) and Wollenberg et al. (2008) described local governance as the granting of formal control by the central government to local governments for both administrative matters and decision-making in multiple sectors.

Decentralization is not a silver-bullet solution to all political problems; handing over power and authority to district governments does not automatically mean increasing welfare for the local people (Djogo and Syaf, 2003). Successful decentralization depends on institution-specific designs that incorporate local participation and accountability (Litvack et al., 1998). A study evaluating the implementation of autonomy laws and their supporting legislation suggests that too much power and authority have been delegated to district governments without appropriate guidance, capacity building, or control mechanisms (cited in Djogo and Syaf, 2003). This power and authority was misused by district officials to enhance their political and business interests, often by restructuring district government and manipulating budget allocations (Djogo and Syaf, 2003).

Due to Indonesia's particular decentralized governance system, it is essential to build capacity for the implementation of REDD + at provincial and, even more importantly, at district levels, in addition to the national level. This includes 
empowering local stakeholders so that they will benefit financially and socially from a REDD+ architecture (UN-REDD, 2010).

\section{DISCUSSION AND CONCLUSIONS}

The forestry sector plays a pivotal role in generating Indonesia's annual greenhouse gas emissions, representing up to $80 \%$ of the country's annual emissions. Peat forests are both carbon sinks and carbon sources; they have the capacity to absorb large volumes of carbon dioxide and store it for long periods. Conversely, due to their high carbon content, disturbance of peat forests quickly releases large amounts of carbon into the atmosphere. Peatland destruction is almost an irreversible process (Boehm and Siegert, 2001); peatland formation takes place over thousands of years (Page et al., 2000) with the gradual storage of huge amounts of carbon. All it takes to destroy the ecosystem and release the carbon is a few poorly planned and carelessly implemented development projects in peatlands.

Rapid deforestation in Indonesia cannot be considered independently of past policy and regulations. Past government policies and institutions have, intentionally or otherwise, discouraged resource conservation (Gillis, 1988). The current government has expressed interest in encouraging sustainability and participating in international climate change mitigation efforts, reflected at various levels of policies and regulation.

Government policies in regard to domestic transmigration, plantation permits and indigenous ownership over forest areas have lead to increasing conflict in land tenure and forest ownership. The dynamics of Indonesia's politics and its decentralization policies include reluctant transfer of power from the possessive central government to the rapacious district governments. All these problems are so intertwined that they cannot be addressed independently. Holistic and integrated approaches are required in designing appropriate solutions to deforestation issue in Indonesia. Unsuitable forestry activity permits should be revoked; it is an essential part in ensuring compliance with current law and preventing further destruction from illegal and unsuitable plantations.

Extreme caution should be exercised in allocating any peatland areas for agricultural development given its disastrous environmental impact. Maintaining soil fertility is difficult in these sites, and in many cases the best long-term economic use will be some form of sustainable forestry. Decisions about large-scale land clearing have often been made with inadequate appreciation of the value of the land under forest. This is particularly true of the value of the forests to local communities who typically derive a substantial proportion of their livelihood from the forest (Byron and Shepherd, 1998).

Despite the efforts of the Indonesian government to reduce deforestation, inconsistencies in policies and regulations related to regional autonomy are glaringly obvious, and represent a grave threat to sustainable management. Most government regulations are not thoroughly evaluated in either the design or implementation phases, and often contradict management schemes at other levels of government (Yuwono, 2001). Policy inconsistencies in Law No. 22/1999 and Government Regulation No. 108/2000 are proof of these misunderstandings, and indicative of a lack of maturity in policy design (Yuwono, 2001). 
REDD+ and forest governance in Indonesia's peat forests are multi-dimensional problems due to conflict of interest within government itself; all aspects - including environmental and sociocultural impact - need to be carefully considered in determining the best adaptive solutions for forestry management and to prevent the unintended impacts from a carelessly planned strategy. As with so many government policies, however, mistakes are often made in the details. If national social, economic and political conditions fail to improve, there is considerable risk that the condition of peat forests in Central Kalimantan will worsen. This would have grave consequences for the hydrology and biodiversity of the Kalimantan region and the climate of South East Asia, and coincident detriment to the livelihoods of local people (cf. Boehm and Siegert, 2001).

The current government of Indonesia has put forward a series of well-intentioned measures to curb deforestation and cut carbon emissions, beginning at COP13 in Bali, where it announced its intention to reduce national emissions by $26 \%$ by 2020 . Indonesia was also the first developing country to develop a legal framework to implement REDD+. The Indonesian Government, however, must still address the sharing of authority and responsibility between government agencies before being able to tap the financial potential of Indonesian forests through a REDD+ mechanism in a responsible fashion. Indonesia's stated intentions to protect its forests seem promising, but the government's degree of commitment to these goals remains to be seen. To the country's detriment, the economic appeal of unsustainable short-term resource consumption still appears to be the driving force behind the acceleration of forest degradation.

\section{REFERENCES}

ALDHOUS, P. 2004. Borneo is burning. Nature. 432: 144-146.

ALVARADO, L. and S. WERTZ-KANOUNNIKOFF. 2007. Why are we seeing 'REDD'? An Analysis of the International Debate on Reducing Emissions from Deforestation and Degradation in Developing Countries. Institut du Dèveloppement Durable et des Relations Internationales (IDDRI), Paris.

BAKORNASPB. 2010. Kebakaranhutandanlahan [Online]. Badan Nasional Penanggulangan Bencana. Accessed 3 April 2010. http://www.bakornaspb.go.id/ website/index.php?option $=$ com_content\&task $=$ view\&id=73\&Itemid $=64$.

BOEHM, H.D.V. and F. SIEGERT. 2001. Ecological impact of the One Million Hectare Rice Project in Central Kalimantan, Indonesia using remote sensing and GIS. In: Proceedings of the 22nd Asian Conference on Remote Sensing, National University of Singapore, 2001.

BYRON, N. and G. SHEPHERD. 1998. Indonesia and the 1997-98 El Niño: fire problems and long-term solutions. Commonwealth Forestry Review. 77(28): 236-236.

CAMPBELL, B. 2009. Beyond Copenhagen: REDD+, agriculture, adaptation strategies and poverty. Global Environmental Change. 19(4): 397-399.

CHATTERJEE, R. 2009. The road to REDD. Environmental Science and Technology. 43(3): 557-560.

COLCHESTER, M., APTE, T., LAFORGE, M., MANDONDO, A. and PATHAK, N. 2003. Bridging the gap: communities, forests and international networks. CIFOR Occasional Paper, Bogor, Indonesia. p. 41. 
CONTRERAS-HERMOSILLA, A. 2001. Forest Law Enforcement. World Bank, Washington DC.

COTULA, L. and J. MAYERS. 2009. Tenure in REDD: Start-Point or Afterthought? International Institute for Environment and Development. London.

CURRAN, L.M., TRIGG, S.N., MCDONALD, A.K., ASTIANI, D., HARDIONO, Y.M. SIREGAR, P., CANIAGO, I. and E. KASISCHKE. 2004. Lowland forest loss in protected areas of Indonesian Borneo. Science. 303(5660): 1000-1003.

DAUVERGNE, P. 1998.The political economy of Indonesia's 1997 forest fires. Australian Journal of International Affairs. 52(1): 13-17.

DIEMONT, W.H., HILLEGERS, P.J.M., JOOSTEN, H., KRAMER, K., RITZEMA, H., RIELEY J. and H. WÖSTEN. 2002. Fire and peat forests, what are the solutions? In: Wise Use of Peatlands, Proceedings of the 12th International Peat Congress, 611 June 2004, Tampere, Finland, J. Päivänen (ed.). Volume 1: 720-725.

DJOGO, T. and R. SYAF. 2003. Decentralization without Accountability: Power and Authority over Local Forest Governance in Indonesia. Responsive Policy Research and Development Project of Forest Resource Governance Program at CIFOR (Centre for International Forestry Research Organization), Bogor, Indonesia.

EUROCONSULT-MOTT MACDONALD and DELTARES. 2008. Master Plan for the Rehabilitation and Revitalization of the Ex-Mega Rice Project Area in Central Kalimantan: A Joint Initiative of the Government of Indonesia and the Netherlands. Government of Indonesia. Palangka Raya.

FIELD, R.D., VAN DER WERF, G.R. and S.S.P. SHEN. 2009. Human amplification of drought-induced biomass burning in Indonesia since 1960. Nature Geoscience. 2: 185-188.

GAVEAU, D., WICH, S., EPTING, J., JUHN, D., KANNINEN, M. and N. LEADERWILLIAMS. 2009. The future of forests and orangutans (Pongoabelii) in Sumatra: predicting impacts of oil palm plantations, road construction, and mechanisms for reducing carbon emissions from deforestation. Environmental Research Letters. 4(3): 340-313.

GIESEN, W. and P.J. MEER 2009. Guidelines for the Rehabilitation of Degraded Peat Swamp Forests in Central Kalimantan (2nd draft). Project Report for Master Plan for the Conservation and Development of the Ex-Mega Rice Project Area in Central Kalimantan. Government of Indonesia, Euroconsult Mott MacDonald, Jakarta. Available at http://edepot.wur.nl/175467.

GILLIS, M. 1988. Indonesia: public policies, resource management, and the tropical forest. In: Public Policies and the Misuse of Forest Resources, R. Repetto and M. Gillis (eds). Cambridge University Press, Cambridge, UK. pp. 43-113.

HIRANO, T., SEGAH, H., HARADA, T., LIMIN, S., JUNE, T., HIRATA, R. and M. OSAKI. 2006. Carbon dioxide balance of a tropical peat swamp forest in Kalimantan, Indonesia. Global Change Biology. 13(2): 412-425.

HOFFMANN, A.A., HINRICHS, A. and F. SIEGERT. 1999. Fire Damage in East Kalimantan in 1997/98 Related to Land Use and Vegetation Classes: Satellite Radar Inventory Results and Proposal for Further Actions. IFFM-SFMP Report, Deutsche Gesellschaftfür Technische Zusammenarbeit, Berlin.

JAENICKE, J., RIELEY, J.O., MOTT, C., KIMMAN, P. and F. SIEGERT. 2008. Determination of the amount of carbon stored in Indonesian peatlands. Geoderma. 147(3-4): 151-158. 
JAUHIANEN, J., TAKAHASHI, H., HEIKKINEN, J.E.P., MARTIKAINEN, P.J. and H. VASANDER. 2005. Carbon flukes from tropical peat swamp forest floor. Global Change Biology. 11(10): 1788-1797.

LEVANG, P. 2003. La terred'en face - La transmigration en Indonèsie. Trans. Sri AmbarWahyuniPrayoga. Institut de recherche pour le développement, Paris.

LITVACK, J.I., AHMAD, J. and R.M. BIRD. 1998. Rethinking Decentralization in Developing Countries. World Bank, Washington DC.

OTSUKA, K., SUYANTO, S., SONOBE, T. and T.P. TOMICH. 2008. Evolution of land tenure institutions and development of agroforestry: evidence from customary land areas of Sumatra. Agricultural Economics. 25(1): 85-101.

PAGE, S.E., RIELEY, J.O., BÖHM, H.D.V. and N.Z. MUHAMAD. 2000. Impact of the 1997 fires on the peatlands of Central Kalimantan, Indonesia. In: Proceedings of the 11th International Peat Congress. Quebec, Canada.

PAGE, S.E., SIEGERT, F., RIELEY, J.O., BOEHM, H.D.V., JAYA, A. and S. LIMIN. 2002. The amount of carbon released from peat and forest fires in Indonesia during 1997. Nature. 420: 61-65.

PARISH, F. 2002. Overview on Peat, Biodiversity, Climate Change and Fire. Global Environment Centre, Kuala Lumpur, Malaysia.

PELUSO, N.L. 2006. Whose woods are these? Counter-mapping forest territories in Kalimantan, Indonesia. In: The Anthropology of Development and Globalization: From Classical Political Economy to Contemporary Neoliberalism, M. Edelmanand and A. Haugerud (eds). Blackwell Publishing, Malden, USA.

PHILLIPS, V.D. 1998. Peatswamp ecology and sustainable development in Borneo. Biodiversity and Conservation. 7(5): 651-671.

PUTRA, E.I., HAYASAKA, H., TAKAHASHI, H. and A. USUP. 2008. Recent peat fire activity in the Mega Rice Project Area, Central Kalimantan, Indonesia. Journal of Disaster Research. 3(5): 334-341.

PYE-SMITH, C. 2010. Sign of growing justice in forest business [Online]. Jakarta: The Jakarta Post. http://www.thejakartapost.com/news/2007/01/23/signs-growingjustice-forest-business.html. Accessed 28 May 2010.

REKLEV, S. 2010. Indonesia puts two-year ban on deforestation [Online]. Beijing: Point Carbon. http://www.pointcarbon.com/news/1.1447936. Accessed 27 May 2010.

RIELEY, J. and S. PAGE. 1996. The biodiversity, environmental importance and sustainability of tropical peat and peatlands. Environmental Conservation. 23(1): 94-95.

SANTILli, M., MOUTINHO, P., SCHWARTZMAN, S., NEPSTAD, D., CURRAN, L. and C. NOBRE. 2005. Tropical deforestation and the Kyoto Protocol. Climatic Change. 71(3): 267-276.

SILVIUS, M. and H. DIEMONT. 2007. Peatlands, climate change, poverty, biofuels, pulp and reduced emissions from deforestation and degradation. Institute for Environmental Studies. Accessed 6 April 2010. http://www.geog.le.ac.uk/ carbopeat/media/pdf/yogyapapers/p36.pdf

SISWANTO, W. 2010. REDD Plus: Policy and Roadmap Jakarta: Ministry of Forestry. http://www.dephut.go.id/files/1.Policy-REDD-plus_Pokja_0.pdf. Accessed 11 May 2010.

SORENSEN, K.W. 1993.Indonesian peat swamp forests and their role as a carbon sink. Chemosphere. 27(6): 1065-1082. 
STRASSBURG, B., TURNER, R.K., FISHER, B., SCHAEFFER, R. and A.A. LOVETT. 2009. Reducing emissions from deforestation: the 'combined incentives' mechanism and empirical simulations. Global Environmental Change. 19(3): 265278.

SUHARMOKO, A. 2010. RI to honour palm oil contract despite forest protection [Online]. Oslo: The Jakarta Post. http://www.thejakartapost.com/news/ 2010/05/27/ri-honor-palm-oil-contracts-despite-forest-protection.html Accessed 28 May 2010.

TERRESTRIALCARBONGROUP. 2009. Policy Briefs 4: Legal and Institutional Foundations for the National Implementation of REDD, lessons from early experience in developing and developed countries [Online]. Terrestrial Carbon Group. http://www.terrestrialcarbon.org/site/DefaultSite/filesystem/documents/ Terrestrial\%20Carbon\%20Group\%20080808.pdf. Accessed 14 May 2010.

UN-REDD 2010. UN-REDD Indonesia Inception Workshop. UN-REDD Program, Jakarta.

VAN BEUKERING, P.J.H., SCHAAFSMA, M., DAVIES, O. and I. OSKOLOKAITE. 2008. The Economic Value of Peatland Resources within the Central Kalimantan Peatland Project in Indonesia. Wetlands International and the University Palangkaraya under the Central Kalimantan Peatlands Project, Unpublished Report. Palangkaraya, Indonesia.

VAYDA, A.P. 2010. Explaining Indonesian forest fires: both ends of the firestick. Human Ecology. 1: 17-35.

VENTER, O., LAURANCE, W., IWAMURA, T., WILSON, K., FULLER, R. and H.P. POSSINGHAM. 2009a. Harnessing carbon payments to protect biodiversity. Science. 326(5958): 1368.

VENTER, O., MEIJAARD, E., POSSINGHAM, H.P., DENNIS, R., SHEIL, D., WICH, S., HOVANI, L. and K. WILSON. 2009b. Carbon payments as a safeguard for threatened tropical mammals. Conservation Letters. 2(10): 123-129.

VERCHOT, L., PETKOVA, E. and I. BOGOR. 2009. The State of REDD Negotiations: Consensus Points, Options for Moving Forward and Research Needs to Support the Process. Unpublished manuscript. CIFOR, Bogor, Indonesia.

WOLlenBERG, E., MOELIONO, M. and G. LIMBERG. 2008. Between State and Society: Decentralization in Indonesia. Earthscan, London.

YUWONO, T. 2001. SalahKaprahOtonomiDaerah di Indonesia [Online]. BAPPENAS. http://els.bappenas.go.id/upload/other/Salah\%20Kaprah\%20Otonomi\%20Daerah\% 20di\%20Indonesia.htm. Accessed 2 May 2010. 